\title{
Called Al-Qur'an Digital Perspective; Answer To Raising Hoax In Era Of Disruption
}

\author{
Risma Savhira D. L., ${ }^{1}$ Alaika M. Bagus Kurnia PS, ${ }^{2}$ Dhomirotul Firdaus ${ }^{3}$ \\ ${ }^{1}$ Universitas Islam Negeri Sunan Ampel Surabaya, Indonesia \\ ${ }^{2}$ Sekolah Tinggi Ilmu Kesehatan Surabaya, Indonesia \\ ${ }^{3}$ Institut Agama Islam Tribakti Kediri, Indonesia

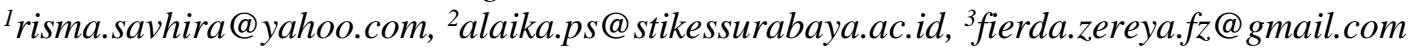

\begin{abstract}
Disruption provides a myriad of benefits to people's lives. However, on the other hand it cannot be denied that the era of disruption has brought quite dangerous obstacles. Due to the lack of a person's moral standing in responding to the era of disruption, resulting in various problems arise. One of the big problems born in the era of disruption is the phenomenon of hoaxes. Hoax is triggered by a lack of attention to ethics in communicating with high social media user numbers. The use of this research writing method takes the form of a conceptual framework and is qualitative in nature. Some literature and observations taken from several media issues related to hoax news as data retrieval, and using a phenomenological analysis approach. This paper produces a digital piety concept that can be implemented through tabayyun attitude Qs review. al-Hujurät verses 6-8, politeness in language review Qs. Tahā verse 44, and local wisdom in the language review Qs. al-Hujurat verse 12 obtained from the study of the contents of the Qur'an.
\end{abstract}

Keywords: Digital piety, disruption, hoaxes, social media, Holy Qur'an.

\begin{abstract}
Abstrak
Disrupsi memberikan segudang manfaat bagi kehidupan masyarakat. Namun, di sisi lain tidak bisa dipungkiri bahwa era disrupsi mengundang hambatan yang cukup membahayakan. Dikarenakan kurangnya kemapanan moralitas seseorang dalam menanggapi era disrupsi, mengakibatkan berbagai masalah muncul. Salah satu permasalahan besar yang lahir di era disrupsi adalah fenomena hoax. Hoax dipicu oleh kurangnya memperhatikan etika-etika dalam berkomunikasi dengan angka pengguna sosial media yang tinggi. Metode penulisan riset ini berbentuk kerangka konseptual dan bersifat kualitatif. Beberapa literatur serta observasi yang diambil dari beberapa isu media terkait berita hoax sebagai pengambilan datanya, dan menggunakan pendekatan analisis fenomenologi. Tulisan ini menghasilkan sebuah konsep kesalehan digital yang dapat diimplementasikan melalui sikap tabayyun dengan tinjauan Qs. al-Hujurat ayat 6-8, kesantunan berbahasa tinjauan Qs. Thahaa ayat 44, dan kearifan lokal dalam berbahasa tinjauan Qs. al-Hujurat ayat 12 yang didapat dari telaah isi kandungan al-Qur'an.
\end{abstract}

Kata Kunci: Kesalehan Digital, Era Distrupsi, Hoaks, Media Sosial, Al Qur'an.

\section{Pendahuluan}

Dinamika kehidupan masyarakat di era saat ini telah mengalami perkembangan yang signifikan. Budaya telah dikorelasi dengan sentuhan teknologi informasi yang 
merupakan fenomena pendorong perubahan masyarakat. Kebebasan mengungkapkan ide, kritik, saran, bahkan hujatan dapat dilihat setiap hari, setiap jam, dan kapanpun dengan tidak terbatas. Kebebasan tersebut dituangkan dalam sosial media. Pasalnya berbagai sosial media memiliki fitur chat dan komentar yang memberikan ruang bagi penggunanya untuk berkomunikasi perihal apapun. Sosial media adalah wadah bagi orang-orang yang ingin berkomunikasi tanpa ada batas jarak dan waktu. Adanya sosial media ini tentu ada efek baik dan buruknya. Dampak positif dari sosial media adalah memudahkan penggunanya berinteraksi dengan banyak orang, memperluas relasi, penyebaran informasi dengan cepat, dan kemudahan dalam berekspresi. Dampak negatifnya adalah dewasa ini marak penyebaran berita palsu (fake news) atau hoax di sosial media online. Selaras dengan survei MASTEL 2017 yang dirilis oleh Kemdikbud RI bahwa penyebaran hoax paling banyak dihasilkan oleh sosial media yaitu sebesar 92,4\%. Disusul dengan aplikasi chat $62,8 \%$, situs web $34,9 \%$, televisi $8,7 \%$, media cetak $5 \%$, email 3,1\%, dan radio $1,2 \%$. Penyebaran berita ini sangat mengkhawatirkan karena tidak hanya membodohi masyarakat dengan kepalsuan, namun juga ada indikasi-indikasi yang ingin memecah belah masyarakat yang pada akhirnya mengarah kepada rusaknya persatuan dan kesatuan.

Berbagai perubahan sosial saat ini telah sampai pada fase fundamental. Karena banyak tata sosial lama yang digantikan oleh bentuk-bentuk baru. Bukan hanya bentuk fisiknya saja, namun perubahan sudah merambah ke substansi sosial. Dari keadaan yang sedemikian rupa menghasilkan nilai-nilai baru yang dikenal dengan era disrupsi. Era disrupsi harus dibarengi dengan sentuhan moralitas. Karena masyarakat di era ini terbiasa dengan kemudahan yang serba ada, sehingga kerangka berpikirnya cenderung instan. Jika moralitas tidak diaplikasikan dalam kehidupan di era disrupsi, maka era disrupsi bukan lagi dimaknai sebagai sebuah keuntungan melainkan dapat mengakibatkan kehancuran.

Beberapa kajian mengenai hoax dan al-Qur'an sudah dilakukan oleh beberapa peneliti terdahulu, Danu Aris Setyanto yang berjudul Hoaks; Teks dan Konteks dalam alQur'an. Penelitian ini membahas tentang berbagai ilustrasi kosakata dalam al-Qur'an yang mengarah kepada hoax dan memberikan solusi-solusi untuk menghadapi hoax seperti mengecek kebenaran berita, meningkatkan literasi, menjauhi prasangka, dan sebagainya. Salwa Sofia Wirdiyana yang berjudul Hoaks dan Al-Qur'an: Upaya Kritis

1 Gallant Karunia Assidik, "KAJIAN IDENTIFIKASI DAN UPAYA PENANGKALAN PEMBERITAAN PALSU (HOAX) PADA PEMBELAJARAN BAHASA INDONESIA,” Kemdikbud RI Badan Pengembangan dan Pembinaan Bahasa (2018). 
dan Beradab dalam Menerima Berita dalam Berkomunikasi. Penelitian merepresentasikan hoax dengan istilah ifk, fasiq, munafiq, murjifun, dan tabayyun. Kemudian menghasilkan kesimpulan yang memuat cara-cara untuk meminimalisir hoax dengan berpikir kritis, kematangan emosi, tabayyun, memperluas wawasan, dan etika berkomunikasi yang baik. Namun, penelitian ini memiliki perbedaan dengan penelitianpenelitian di atas. Diantaranya, penelitian ini mengupas latar belakang maraknya hoax dengan fenomena sosial terkini yaitu disrupsi. Penelitian ini juga membahas media-media penyebaran hoax yang marak di tengah masyarakat. Penelitian ini ditutup dengan aktualisasi kesalehan digital yang berisi langkah-langkah menekan penyebaran hoax yang sesuai dengan nilai-nilai berbagai surah dalam al-Qur'an.

Atas dasar history di atas, maka penulis akan memaparkan tentang kondisi di era disrupsi; media sosial dengan permasalah dan etika penggunaannya; serta mengkaji aktualisasi kesalehan digital perspektif agama dan ayat-ayat al-Qur'an sebagai tawaran atas langkah-langkah yang dapat ditempuh untuk menghadapi hoax.

\section{Metode}

Diskusi pada riset ini adalah riset yang berbentuk deskriptif kualitatif. Dikatakan deskriptif karena menjelaskan alur penelitiannya bersifat deduktif ${ }^{2}$. Dari beberapa konsep yang dituangkan pada sub bab, dikaitkan dengan beberapa data fenomena sebagai media analisisnya. Sehingga beberapa data yang diambil berasal dari beberapa referensi ${ }^{3}$ terkait. Baik referensi primer maupun sekunder sebagai pisau analisis konseptual. Selanjutnya, karena penelitian ini menggunakan pendekatan fenomenologi, maka perlu beberapa dokumentasi data atas informasi-informasi yang terkait sebagai bahan diskusi, reduksi hingga kesimpulannya yang menjadi dialog akhir dengan beberapa sumber referensi sebagai alat analisis sosial.

\section{Hasil dan Pembahasan}

\section{Era Disrupsi; Inovasi dan Hambatan}

Berbicara tentang teknologi zaman ini sangat erat kaitannya dengan disrupsi. Karena, ciri-ciri era disrupsi adalah banjirnya informasi yang menyebabkan tidak ada lagi batas-batas dunia. Selain itu teknologi juga mengubah pola pikir manusia dari time series

${ }^{2}$ A. Muri Yusuf, Penelitian Kuantitatif, Kualitatif \& Penelitian Gabungan (Jakarta: Prenada Media, 2016).

${ }^{3}$ James Danandjaja, Metode Penelitian Kepustakaan (Antropologi Indonesia, 2014).

Tribakti: Jurnal Pemikiran Keislaman

Volume 31, Nomor 2, Juli 2020 
menjadi real time ${ }^{4}$. Buktinya, teknologi meruntuhkan penghalang bagi semua orang dan memungkinkan adanya akses dimana saja dan kapan saja termasuk informasi dari berbagai pengambil keputusan. Berbagi berita lintas batas, melampaui perkembangan saluran, telah melahirkan peristiwa-peristiwa baru. Batas-batas keluarga, suku, dan geografis hilang. Nilai-nilai, minat, dan tujuan yang sama bagi masyarakat telah membangkitkan umat digital, yaitu sebuah ruang global yang kuat untuk mewadahi identitas mereka. ${ }^{5}$ Salah satu contoh konkritnya adalah adanya perubahan perilaku masyarakat dalam literasi. Literasi umumnya didapat dari buku-buku, koran, majalah dan kegiatan belajar mengajar di sekolah, yang cara mendapatkannya perlu estimasi waktu khusus. Berbeda dengan saat ini, literasi tersebut bisa didapat dengan real time melalui sosial media instagram, twitter, facebook, dan lain sebagainya. Literasi digital tersebut menjalin integrasi antara dunia nyata dan dunia maya, agar masyarakat dapat berpartisipasi secara efektif ${ }^{6}$ dengan memanfaatkan sosial media. Seperti pada akun instagram@bank_indonesia, akun ini memberi informasi terkait kebijakan-kebijakan yang dikeluarkan oleh Bank Indonesia, bahkan beberapa waktu lalu akun ini melakukan siaran langsung di instagram yang dapat dilihat oleh masyarakat umum terkait penetapan suku bunga.

Dilihat dari manfaat ekspansi teknologi di atas, seperti tidak terjadi masalah apapun di era disrupsi. Kemudahan dan kecepatan dapat memudahkan segala aktivitas kehidupan manusia. Harga yang murah dengan kualitas bagus adalah dambaan semua orang termasuk akses yang mudah menghubungkan semua lini. Namun di sisi lain ada sebuah dimensi mendasar yang terdampak negatif dari era disrupsi, yaitu moralitas. ${ }^{7}$ Kebebasan dalam berekspresi dan kemudahan justru membuat sebagian orang hilang kendali bahkan mengabaikan norma-norma yang ada. Salah satu contoh misalnya, saat ini setiap orang selalu ingin menjadi yang pertama kali mengabarkan berita jika ada sebuah peristiwa yang terjadi. Demi menjadi orang yang pertama, mereka mengabaikan kaidah-kaidah dalam mengabarkan berita, seringkali berita yang dikabarkan hanya

\footnotetext{
4 Naimatus Tsaniyah and Kannisa Ayu Juliana, "LITERASI DIGITAL SEBAGAI UPAYA MENANGKAL HOAKS DI ERA DISRUPSI," Al Balagh: Jurnal Dakwah dan Komunikasi 4, no. 1 (2019): $121-140$. 2016).

${ }^{5}$ Shelina J. Mohammed, Generation M: Young Moslem Changing The World (London: I. B. Taurs,

${ }^{6}$ Rila Setyaningsih et al., "Model Penguatan Literasi Digital Melalui Pemanfaatan E-Learning," Jurnal ASPIKOM 3, no. 6 (2019): 1200.

${ }^{7}$ Cendekiawan Islam Jawa Barat dan Banten, Moderasi Islam di Era Disrupsi (Yogyakarta: Pustaka Senja Imprint Ganding Pustaka, 2018).
} 
sepotong-sepotong dan menjadi fake news (berita palsu). Selain itu, disini dapat terlihat bahwa pekerjaan wartawan telah di disrupsi oleh orang lain dan kecepatan teknologi justru mengakibatkan dampak negatif.

Aspek positif dan negatif di atas jelas memiliki pengaruh yang sangat kuat terhadap pergaulan, khususnya bagi masyarakat Islam di era disrupsi. Masyarakat harus beradaptasi dan mengakomodasi sebagiannya karena merupakan tuntunan agama Islam. Pada saat yang sama masyarakat harus selektif, sebab banyak model, bentuk, dan substansi pergaulan yang perlu dinilai kebenarannya dalam perspektif moralitas dan legalitas, serta menguntungkan atau sebaliknya menghancurkan bagi keberlangsungan hidup masyarakat. Oleh karena itu, dimensi perubahan seharusnya disambut sebagai media untuk mengembangkan kehidupan yang lebih modern, namun tetap dalam bingkai kebenara ajaran Allah SWT. Karena dalam Islam ilmu saja tidak cukup, melainkan harus dibarengi dengan adab dan akhlak yang baik. $^{8}$

Islam tidak sepenuhnya menutup mata dalam menanggapi perubahan dan teknologi yang berkembang saat ini. Beberapa sikap Islam terhadap perubahan dan teknologi antara lain; pertama, Islam menerima bahkan mendorong dan mengajarkan pemeluknya untuk melakukan perubahan serta modernitas. Perubahan dan modernitas sejatinya adalah sesuatu yang fundamental dan esensial bagi masyarakat, karena hal tersebut tidak lain adalah wujud perjuangan untuk mempertahankan eksistensi hidup yang sejalan dengan firman Allah pada Qs. ar-Ra'd ayat 11.

Kedua, Islam dapat menerima penggunaan unsur-unsur budaya barat. Tentu saja budaya tersebut harus sesuai dengan nilai-nilai fundamental dalam Islam. Seperti penggunaan teknologi yang sangat dibutuhkan oleh masyarakat agar Islam semakin maju dan dikenal dunia. ${ }^{9}$ Dari beberapa pandangan Islam terhadap modernitas dan teknologi, dapat disimpulkan bahwa masyarakat tidak bisa menutup mata terhadap perubahan yang ada, namun yang bisa dilakukan hanyalah membentengi diri dari unsur-unsur negatif dari perubahan tersebut.

${ }^{8}$ Syahrin Harahap, Islam \& Modernitas: Dari Teori Modernisasi Hingga Penegakan Kesalehan Modern (Jakarta: Penamedia Grup, 2015).

9 Faisal Ismail, Islam Yang Produktif: Titik Temu Visi Keumatan dan Kebangsaan (Yogyakarta: IRCiSoD, 2017). 


\section{Media Sosial \& Etika Penggunaan}

Teknologi informasi saat ini mengalami perkembangan yang sangat pesat dan merupakan sebuah trend yang tidak dapat dibendung lagi. Terbukti dengan adanya arus informasi yang sangat pesat di masyarakat, teknologi informasi telah mengantar perkembangan di berbagai aspek kehidupan masyarakat. ${ }^{10}$ Salah satu bentuk dari perkembangan teknologi informasi yang memiliki pengaruh besar adalah sosial media. Sosial media digunakan sebagai sarana melihat, memproduksi, dan menyebarkan informasi. Sosial media memberi peluang bagi siapa saja untuk memperluas interaksi sosial dengan membagi informasi, memberikan feedback atas informasi yang didapat, atau hanya sekedar melihat saja. ${ }^{11}$

Media memiliki makna sebagai alat untuk berkomunikasi, sedangkan sosial diartikan sebagai interaksi masyarakat. Artinya, setiap individu tidak dapat hidup secara mandiri secara mutlak. ${ }^{12}$ Media sosial juga dapat diartikan sebagai alat komunikasi yang digunakan para penggiat sosial untuk berkomunikasi secara tepat, cepat, dan tanpa batas.

\section{Penggunaan Media Sosial}

Masa depan media sosial sulit diprediksi, karena keberadaannya semakin tidak bisa dipisahkan dengan kehidupan manusia. Hal itu trejadi karena melihat fungsi dan manfaatnya membuat hidup manusia lebih mudah, efektif, dan efisien. Selain itu media sosial terus-menerus berbenah untuk melayani hajat hidup manusia.

Data yang diluncurkan oleh Google consumer behaviour menyatakan bahwa 132,7 juta masyarakat Indonesia menjadi pengguna media sosial dari total penduduk yaitu 265,4 juta. ${ }^{13}$ Dengan rincian presentase pengguna platform sosial media yang dikeluarkan oleh Global Web Index tahun 2019 dibawah ini, youtube memimpin di angka mendekati $90 \% .^{14}$

10 Amar Ahmad, "Perkembangan Teknologi Komunikasi dan Kesenjangan Informasi: Akar Informasi dan Berbagai Standarnya," Jurnal Dakwah Tabligh 13, no. 1 (2012): 137-149.

${ }^{11}$ Rohma Fahlepi Doni, "Perilaku Penggunaan Smartphone pada Kalangan Remaja," Journal Speed Sentra Penelitian Engineering dan Edukasi 9, no. 2 (2017): 16-23.

${ }^{12}$ Mulawarman Mulawarman and Aldila Dyas Nurfitri, "Perilaku Pengguna Media Sosial Beserta Implikasinya Ditinjau dari Perspektif Psikologi Sosial Terapan,” Buletin Psikologi 25, no. 1 (2017): 36-44.

13 Lucy Pujasari Supratman, "Penggunaan Media Sosial oleh Digital Native," Jurnal ILMU KOMUNIKASI 15, no. 1 (2018): 47-60.

14 Lipsus Internet, "Indonesia Digital 2019: Media Sosial," Websindo, last modified 2019, https://websindo.com/indonesia-digital-2019-media-sosial/. 


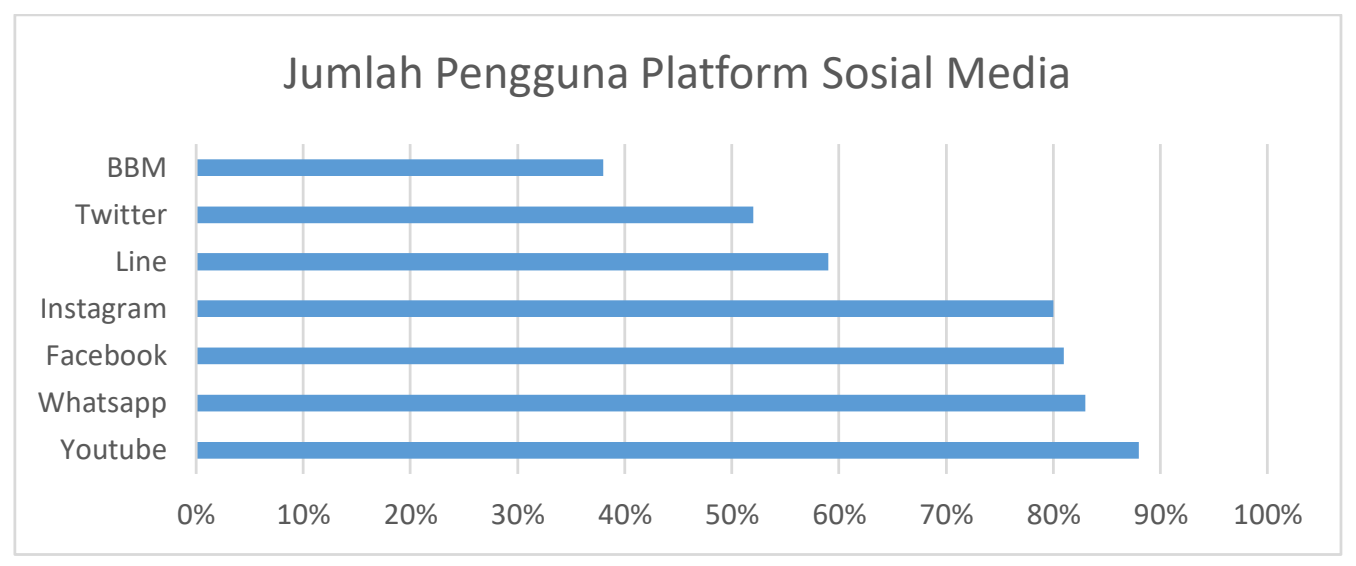

Angka-angka tersebut membuktikan bahwa dari tahun ke tahun eksistensi media sosial semakin meningkat. Indonesia sendiri sudah memprediksi bahwa beberapa tahun ke depan penggunanya akan semakin tajam karena media sosial digunakan di semua lini. Di bidang pendidikan misalnya, pelajar tidak perlu susah payah untuk datang ke bimbingan belajar guna memperdalam ilmunya, cukup menggunakan aplikasi Ruang Guru yang bisa diakses dimanapun dan kapanpun. Selain itu, di bidang perbankan saat ini semua bank sudah memiliki platform mobile banking untuk mempermudah nasabahnya dalam bertransaksi.

\section{Masalah Sosial dalam Media Sosial}

Perkembangan teknologi informasi dengan sosial media secara umum sangat menguntungkan penggunanya. Karena pengguna dapat berkomunikasi dengan jarak jauh dengan cepat, dan memperoleh informasi di luar batas negara dengan sangat efektif. Namun di samping itu, tidak jarang adanya penyelewengan penggunaan sosial media. Sosial media digunakan untuk mengujar kebencian, menyebarkan informasi bohong, pencemaran nama baik, hingga ancaman kepada suatu individu atau kelompok. Hoax adalah salah satu fenomena yang booming saat ini. Hoax adalah penyebaran informasi yang masif tidak berdasarkan data yang valid sebagai tipuan untuk memperdaya masyarakat. ${ }^{15}$ Menurut Cambridge Dictionary hoax adalah rencana untuk menipu sekelompok orang. ${ }^{16}$ Hoax merupakan informasi sesat yang berbahaya kerena menyebabkan turunnya kredibilitas dan kehilangan kepercayaan secara sosial, dalam kehidupan bermasyrakat hoax dapat memicu perselisihan, keributan, serta ketidaktenangan kehidupan bermasyarakat. Hoax bertujuan untuk mempengaruhi

${ }^{15}$ Iffah Al Walidah, “Tabayyun Di Era Generasi Millenial,” Jurnal Living Hadis 2, no. 2 (2018): 317. ${ }^{16}$ Ibid.

Tribakti: Jurnal Pemikiran Keislaman Volume 31, Nomor 2, Juli 2020 
pembaca dengan informasi palsu sehingga pembaca mengambil tindakan sesuai hoax yang diterima ${ }^{17}$.

Hoax sebenarnya bukan kejadian baru di era millenial. Jika kita flashback dalam sejarah nabi-nabi, banyak sekali ditemukan beberapa hoax pada waktu itu. Salah satu contoh adalah hoax yang menyangkut manusia pertama di bumi yaitu nabi Adam as. Nabi Adam menjalani konsekuensi dikeluarkan dari surga dan dipisahkan denga Siti Hawa dikarenakan mendapat berita bohong dari iblis, sehingga nabi Adam dihukum oleh Allah. Fenomena hoax terus berlanjut sampai masa nabi terakhir yaitu nabi Muhammad SAW., bahkan hoax sangat marak terjadi di zaman akhir seperti ini. Seperti kasus hoax yang menimpa KH. Musthofa Bisri, yang menyebutkan bahwa keinginan Habib Riziq bukan sekedar menjadi penguasa, namun ingin menjadi Tuhan seperti Fir'aun agar disembah semua orang. Hal tersebut tentu membuat para pengikut Habib Riziq terganggu sehingga menyerang Gus Mus dan kelompoknya. ${ }^{18}$

\section{Etika Penggunaan Media Sosial}

Media sosial telah memberikan manfaat yang sedemikian rupa untuk memudahkan penggunanya dalam melakukan interaksi sosial. Namun dibalik manfaatnya, saat ini terdapat sisi-sisi negatif yang dimanfaatkan oleh oknum tidak bertanggung jawab. Sisi-sisi negatif tersebut terjadi karena dalam penggunaannya tidak dilandasi dengan etika berkomunikasi yang baik.

Etika sendiri adalah segala hal terkait baik-buruk dan benar-salah atas perilaku dalam berasyarakat. ${ }^{19}$ Etika dinilai sebagai landasan normatif bagi kehidupan sosial masyarakat. Karena sebuah tatanan masyarakat akan baik, tentram, dan damai jika stakeholder di dalamnya memiliki etika yang baik. Dari aspek wujudnya dalam masyarakat, etika dibagi menjadi dua jenis, yaitu etika tertulis dan etidak tidak tertulis. Etika tertulis adalah etika yang berdasarkan kesepakatan dan memiliki legalitas yang disahkan dalam bentuk peraturan untuk dipatuhi masyarakat. Salah satu etika tertulis berdasarkan perundang-undangan, yaitu UU Nomor 11 tahun 2008 tentang Informasi dan

${ }^{17}$ Errissya Rasywir and Ayu Purwarianti, “Import Citahttp://Eksperimen Pada Sistem Klasifikasi Berita Hoax Berbahasa Indonesia Berbasis Pembelajaran Mesin,” Jurnal Cybermatika 3, no. 2 (2015): 18, https://www.mendeley.com/import/.

18 "Hati-Hati, Ini Meme 'Hoax' Atasnamakan Gus Mus," NU Online, https://www.nu.or.id/post/read/75988/hati-hati-ini-meme-hoax-atasnamakan-gus-mus.

${ }^{19}$ M. Nur Prabowo Setyabudi, Pengantar Studi Etika Kontemporer (Malang: Universitas Brawijaya Press, 2017). 
Transaksi Elektronik (UU ITE). Adapun etika tidak tertulis adalah sopan santun dan norma-norma yang muncul dengan sendirinya melalui proses interaksi masyarakat.

Selain etika tertulis dan etika tidak tertulis, al-Qur'an sebagai pedoman hidup manusia juga telah menjelaskan dengan gamblang mengenai etika berkomunikasi. Allah berfirman dalam al-Qur'an dalam surat al-Hujarat ayat 11 yang menjelaskan tentang beberapa sikap yang harus dihindari sebagai pencegah pertikaian.

Surat tersebut memberi petunjuk tentang sikap-sikap yang harus dihindari agar tidak timbul pertikaian. Allah melarang hambanya mengolok-olok, menghina, dan mengancam orang lain, karena bisa jadi orang yang dihina justru lebih baik dari yang menghina. ${ }^{20}$ Dalam konteks etika dalam berkomunikasi, ayat ini menghimbau agar senantiasa berhati-hati dalam bersikap, bertutur kata, dan menyampaikan pendapat secara langsung maupun di media sosial agar tidak menyakiti orang lain. Karena sesungguhnya, permasalahan-permaslahan yang timbul di media sosial berawal dari perbedaan pendapat yang diperkeruh dengan hinaan dan celaan sehingga pihak yang berselisih semakin emosi.

\section{Aktualisasi Kesalehan Digital}

\section{Tabayyun}

Jauh sebelum era millenial saat ini, Allah SWT memberikan pelajaran kepada umatnya tentang bagaimana seharusnya bersikap kepada orang fasik dan pentingnya mengecek kebenaran informasi yang kita terima secara individu atau yang sudah beredar di masyarakat. Rasulullah juga prihatin dengan beredarnya hoax karena seperti yang telah diketahui bahwa dampak yang ditimbulkan sangat merugikan. Pandangan Islam tentang hoax semata-mata dengan tujuan untuk menciptakan kemaslahatan umat, Rasulullah tidak ingin umatnya terlena dalam kebodohan. al-Qur'an secara gamblang telah menjelas tentang hoax, sebagaimana dalam Qur'an Surah al-Hujurat ayat 6:

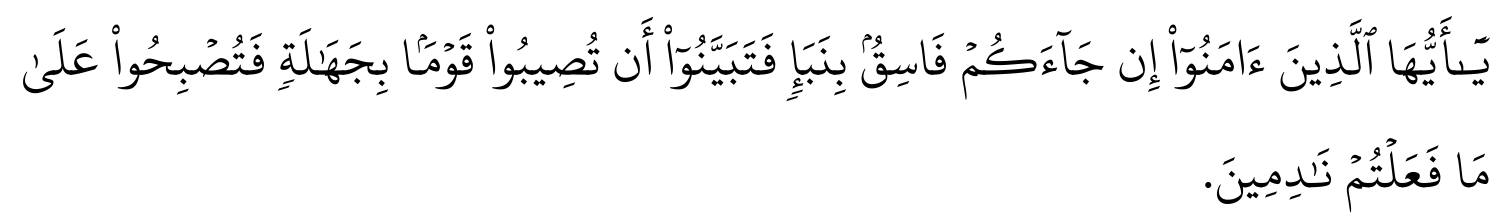

Terjemahnya: Hai orang-orang yang beriman, jika datang kepadamu orang fasik membawa suatu berita, maka periksalah dengan teliti agar kamu tidak menimpakan suatu musibah kepada suatu kaum tanpa mengetahui keadaannya yang menyebabkan kamu menyesal atas perbuatanmu itu. ${ }^{21}$

${ }^{20}$ M. Quraish Shihab, Tafsir Al-Misbah: Pesan, Kesan, dan Keserasian al-Qur'an, Vol. 13. (Jakarta: Lentera hati, 2002).

${ }^{21}$ Presiden Republik Indonesia, Presiden Republik Indonesia, al-Qur'an dan Terjemah Dilengkapi Panduan Waqaf dan Ibtida' (Jakarta, 2016).

Tribakti: Jurnal Pemikiran Keislaman

Volume 31, Nomor 2, Juli 2020 
Jumhur ulama' mengatakan, turunnya ayat ini menyangkut kisah al Walid Ibn 'Uqbah Ibn Abi Mu'ith yang ditugaskan Rasulullah SAW ke Bani al Musthalaq untuk memungut zakat. Ketika anggota masyarakat yang dituju itu mendengar tentang kedatangan utusan nabi SAW., mereka keluar dari perkampungan dan menyambutnya sambil membawa sedekah mereka, tetapi al Walid menduga bahwa penduduk kampung akan menyerangnya. Al Walid pun kembali ke nabi SAW dan melapor bahwa Bani al Musthalaq enggan membayar zakat dan akan menyerang nabi SAW. Mendengar laporan tersebut, Rasulullah marah dan mengutus al Walid untuk menyelidik keadaan yang sebenarnya dan tidak menyerang Bani al Musthalaq sebelum jelas duduk perkaranya. Khalid Ibn Walid mengutus seorang informan menyelidiki kondisi Bani al Musthalaq yang ternyata mereka sedang mengumandangkan adzan dan melaksanakan shalat berjamaah. Kemudian Khalid Ibn Walid pun mengunjungi mereka lalu menerima zakat yang telah mereka kumpulkan. ${ }^{22}$

Kata 'fasik' adalah seseorang yang tidak diketahui dengan jelas kebenaran dan keadilannya. Ibnu katsir mengartikan fasik sebagai dosa-dosa besar. Padahal kata fasik digunakan untuk orang yang tidak pernah melakukan ketaatan dan orang mukmin yang paling rendah. Maka begitu jeleknya orang yang menyebarkan berita bohong sampaisampai disejajarkan dengan orang yang tidak pernah melakukan ketaatan. Kata "naba,", berarti berita penting. Berbeda dengan khabar yang artinya adalah berita secara umum, penting maupun tidak penting. Dari perbedaan tersebut dapat dilihat bahwa pentingnya memilah berita yang penting atau tidak untuk dikonsumi dan berita yang benar atau tidak. Maka jika mendapat berita dari orang fasik sebaiknya "fatabayyanu” yaitu carilah kebenaran kabar berita dengan sungguh-sungguh. Menurut kalimat tersebut al Tabari mengatakan "selidikilah dulu sehingga kalian mengetahui kebenarannya jangan terburuburu menerimanya”. Jika tidak maka yang terjadi adalah "an tushibu qouman bi jahalah" yaitu kehancuran akan menimpa suatu kaum akibat kebodohannya tidak menyaring berita sebelum dikonsumsi. Kemudian pada kalimat "fatushbihu 'ala ma fa'altum nadimin" mengisyaratkan penyesalan seseorang tatkala ia telah melakukan suatu kesalahan. Penyesalan dalam konteks ini berarti seseorang yang tidak menyaring kebenaran suatu informasi. ${ }^{23}$

${ }^{22}$ M. Quraish Shihab, Tafsir Al-Misbah: Pesan, Kesan, dan Keserasian al-Qur'an, Vol. 12. (Jakarta: Lentera hati, 2002).

${ }^{23}$ Muhammad Ali Ash Shabuni, Shafwatut Tafasir, Juz 3. (Mesir: Dar al-Shobuni, n.d.). 
Syekh Mustafa al Maraghi dalam tafsir al Maraghi berkata, Allah SWT mendidik hamba-hambaNya yang mukmin dengan sifat sopan yang berguna bagi mereka dalam soal agama atau dunia. Dalam konteks ini, apabila mereka dihampiri dengan orang fasik yang terang-terangan meninggalkan syiar agama dan membawa suatu berita hendaklah tidak terus mempercayainya sehingga betul-betul mendapat kepastian dan berusaha mengetahui perkara yang sebenarnya dan jangan mudah bersandar kepada perkataannya. Karena orang yang mudah melakukan kefasikan tentu juga mudah melakukan dusta. ${ }^{24}$

Ayat di atas merupakan salah satu dasar yang ditetapkan agama dalam kehidupan sosial sekaligus ia merupakan tuntunan yang sangat logis bagi penerima dan pengamalan suatu berita. Kehidupan manusia dan interaksinya harus didasarkan hal-hal yang diketahui dengan jelas. Manusia tidak dapat memebendung semua informasi yang ada, maka perlunya pihak lain yang jujur dan berintegritas tinggi sehingga menyampaikan halhal yang benar. Perlunya menyaring berita sangat ditekankan karena agar tidak sampai ada orang yang melakukan kebodohan atau dalam ayat ini disebut bi jahālah yang dapat menyebabkan turunnya musibah.

Qs al-Hujurat ayat 6 telah memerintahkan kaum beriman untuk meneliti kebenaran suatu berita. Selanjutnya pada Qs. Al-Hujurat ayat 7 di bawah ini menjelaskan tentang sikap yang harus dilakukan untuk menghadapi hoax yang berkembang di masyarakat.

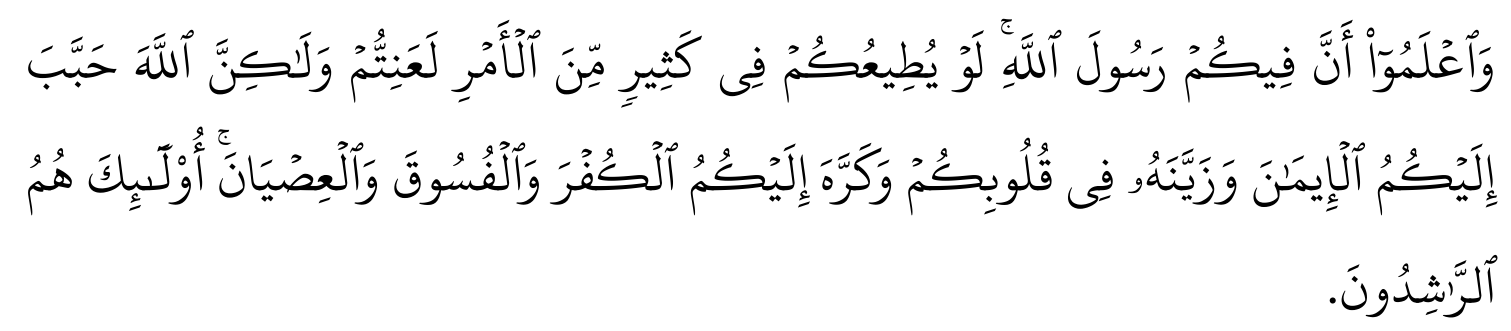

Terjemahnya: Dan ketahuilah olehmu bahwa di kalanganmu ada Rasulullah. Kalau ia menuruti kemauanmu dalam beberapa urusan benar-benarlah kamu mendapat kesusahan, tetapi Allah menjadikan kamu "cinta" kepada keimanan dan menjadikan keimanan itu indah di dalam hatimu serta menjadikan kamu benci kepada kekafiran, kefasikan, dan kedurhakaan. Mereka itulah orang-orang yang mengikuti jalan yang lurus. ${ }^{25}$

\footnotetext{
${ }^{24}$ Fatin Nazmin Mansor \& Nik Mohd Nabil B Ibrahim @, Nik Hanafi Wan Hakimin, "Kepentingan Tabayyun Dalam Mendepani Arus Globalisasi," 4th INTERNATIONAL CONFERENCE ON ISLAMIYYAT $\begin{array}{lccc}\text { STUDIES } & \text { 2018, no. } & \text { September } & \text { (2018): } \\ \text { http://conference.kuis.edu.my/irsyad/images/eproceeding/2018/1068-irsyad-2018.pdf. }\end{array}$

${ }^{25}$ Departemen Agama Republik Indonesia, al-Qur'an dan Terjemahnya (Surabaya: Mahkota, 1991).
} Tribakti: Jurnal Pemikiran Keislaman Volume 31, Nomor 2, Juli 2020 
Dalam menghadapi berita hoax yang semakin hari semakin mengepung masyarakat dalam ketidakberdayaan, maka perlunya langkah-langkah solutif sebagai jawaban atas keresahan masyarakat. Adapun beberapa langkah yang dapat ditempuh dalam menghadapi hoax di media sosial menurut perspektif ayat al-Qur'an di atas adalah sebagai berikut:

Pertama, Berpegang teguh kepada sunnah. Berpegang teguh kepada sunnah berarti merujuk kepada sumber yang mempunyai wewenang atau dapat dipercaya. Dalam hal ini adalah Rasulullah. Rasulullah selalu mencontohkan bahwa beliau adalah penyabar dan pemaaf. Maka dalam konteks ini, apabila mendapat sebuah kabar yang tidak benar atau hoax hendaklah tetap meneladani sikap Rasulullah yang penyabar dan pemaaf agar tidak terpancing emosi. Sebaliknya jika tidak berpegang teguh kepada sunnah, seseorang akan terbawa arus hoax dan mengakibatkan kehancuran.

Kedua, Mengedepankan keimanan di atas segala hal. Dengan mengdepankan keimanan, hati seseorang akan selalu waspada dalam menanggapi berita-berita yang tersebar. Selain itu, seseorang akan bijak menanggapi apapun yang terjadi dalam dirinya.

Ketiga, Menjauhi sifat-sifat kekafiran, kefasikan, dan kedurhakaan. Hoax mengakibatkan berbagai perbuatan-perbuatan tercela yang mengganggu kehidupan bermasyarakat. Seseorang hendaknya menjauhi perbuatan-perbuatan tercela yang tidak ada gunanya. Karena perbuatan-perbuatan tercela yang diakibatkan oleh hoax seperti mencaci maki, terpancing emosi, bahkan demo. Selain merugikan diri sendiri dan orang lain, perbuatan tersebut termasuk golongan fasik yaitu dosa-dosa besar.

\section{Santun dalam Berbahasa}

Santun adalah sebuah sikap yang memuat perilaku yang ditetapkan oleh mayoritas masyarakat untuk menjadi landasan dalam tatanan sosial. Bahasa sebagai saran berkomunikasi memegang peranan penting dalam kehidupan manusia untuk menyampaikan pesan kepada lawan komunikasi. Namun, dewasa ini banyak orang tidak sadar telah mengabaikan aturan norma-norma dalam berbahasa. Akibatnya banyak terjadi celaan, hinaan, bahkan kekerasan yang ditimbulkan dari ketidak santunan dalam berbahasa. ${ }^{26}$ Sejalan dengan firman Allah dalam Qs. Ṭāhā (20) ayat 44:

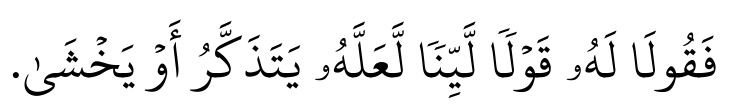

${ }^{26}$ St. Mislikhah, "Kesantunan Tuturan," Ar-Raniry: International Journal of Islamic Studies 1, no. 2 (2014): 285-296. 
Terjemahnya: Maka berbicaralah kamu berdua kepadanya dengan kata-kata yang lemah lembut, mudah-mudahan ia ingat atau takut. 27

Ayat ini merupakan petunjuk dari Allah kepada nabi Musa a.s dan nabi Harun a.s ketika mereka akan mendatangi Fir'aun. Ayat ini menghimbau agar tetap berkata lemah lebut kepada lawan. Karena dengan perkataan yang lemah lembut akan mengundang empatinya dan membuat mereka takut kepada Allah. ${ }^{28}$ Cara seperti ini dapat diimplementasikan oleh masyarakat sebagai sarana untuk berkomunikasi secara langsung atau tidak langsung. Jika semua pihak bertutur kata santun, maka tidak akan ada yang merasa disakiti dan kehidupan bermasyarakat menjadi tentram dan damai.

\section{Kearifan Lokal dalam Berbahasa}

Kearifan lokal yang juga dikenal dengan local wisdom adalah gagasan-gagasan lokal memuat nilai etika, pedoman, dan tradisi yang ditanamkan kepada masyarakat setempat dan menghiasi jalannya kehidupan di sebuah daerah ${ }^{29}$. Kearifan lokal mencerminkan identitas suatu daerah yang berbentuk tradisi turun-temurun yang diwariskan oleh nenek moyang. Jika melihat latar belakang Indonesia yang berbeda ras, agama, dan bahasa, tentu tidak salah jika kearifan lokalnya pun sangat beragam ${ }^{30}$.

Kearifan lokal dalam berbahasa merupakan ekspresi komunikasi suatu warga yang disebarkan dari mulut ke mulut. Salah satu dari ragam kearifan lokal yang digunakan sebagai pedoman berkomunikasi adalah syi'ir. Syi'ir adalah bentuk puisi klasik jawa yang merupakan hasil dari pengalaman penulis yang disampaikan melalui bahasa dengan ringkas dan puitis. Syi'ir mengandung amanat-amanat yang dapat diimplementasikan dalam berkomunikasi sehari-hari.

Salah satu syi'ir yang dimanfaatkan untuk jawaban sebagai penangkal hoax adalah "syi'ir tanpo waton" karangan KH. Nizammuddin yang sudah tidak asing di telinga masyarakat.

Akeh kang apal Qur'an hadiste

Seneng ngafirke marang liyane

Kafire dewe gak di gatekke

\footnotetext{
${ }^{27}$ Indonesia, Presiden Republik Indonesia, al-Qur'an dan Terjemah Dilengkapi Panduan Waqaf dan Ibtida'.

${ }^{28}$ M. Quraish Shihab, Tafsir Al-Misbah: Pesan, Kesan, dan Keserasian al-Qur'an, Vol. 8. (Jakarta: Lentera Hati, 2002).

${ }^{29}$ Sartini, “Abstract: Kata Kunci:," Jurnal Filsafat 37, no. 2 (2004): 111-120

30 Verawati Ade and Idrus Affandi, "IMPLEMENTASI NILAI-NILAI KEARIFAN LOKAL DALAM MENGEMBANGKAN KETERAMPILAN KEWARGANEGARAAN (Studi Deskriptif Analitik Pada Masyarakat Talang Mamak Kec. Rakit Kulim, Kab. Indragiri Hulu Provinsi Riau)," Jurnal Pendidikan Ilmu Sosial 25, no. 1 (2016): 77.
}

Tribakti: Jurnal Pemikiran Keislaman

Volume 31, Nomor 2, Juli 2020 


\section{Yen isih kotor ati akale}

Dalam syi'ir tersebut para pembaca dituntun untuk tidak merendahkan orang lain meskipun telah memiliki ilmu yang tinggi. Selaras dengan firman Allah pada Qs. alHujurāt ayat 12 yang melarang seseorang untuk menilai keburukan tanpa adanya dasar yang jelas. Dengan menghindari dugaan dan prasangka buruk, maka kehidupan masyarakat akan tenang dan produktif, karena waktu yang mereka gunakan tidak siasia. $^{31}$

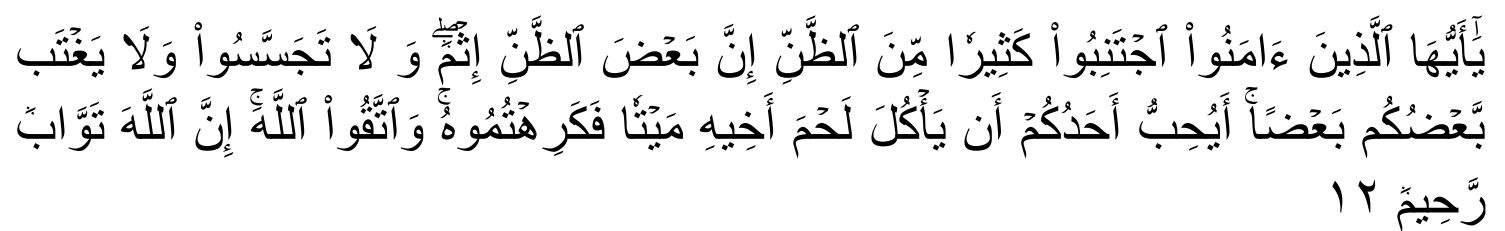

Terjemahnya: Hai orang-orang yang beriman, jauhilah kebanyakan purba-sangka (kecurigaan), karena sebagian dari purba-sangka itu dosa. Dan janganlah mencari-cari keburukan orang dan janganlah menggunjingkan satu sama lain. Adakah seorang diantara kamu yang suka memakan daging saudaranya yang sudah mati? Maka tentulah kamu merasa jijik kepadanya. Dan bertakwalah kepada Allah. Sesungguhnya Allah Maha Penerima Taubat lagi Maha Penyayang. ${ }^{32}$

\section{Kesimpulan}

Penelitian ini menemukan beberapa konsep kesalehan digital sebagai penguatan moral untuk menghadapi hoax di era disrupsi. Konsep kesalehan digital ini merupakan implementasi dari beberapa firman Allah dalam al-Qur'an, seperti aplikasi sikap tabayyun, kesantunan berbahasa, dan kearifan lokal dalam berbahasa. Tabayyun merupakan suatu keharusan implikasi ketika mendapatkan berita, menilik apakah berita tersebut benar atau salah. Sedangkan kesantunan berbahasa dan kearifan lokal merupakan sikap yang diimplementasikan ketika berkomunikasi di dunia nyata maupun di media sosial. Hal tersebut dilakukan untuk mencegah terjadinya gesekan-gesekan antar masyarakat yang dapat memperkeruh keadaan. Adanya konsep-konsep ini diharapan dapat menjadi pegangan masyarakat di tengah maraknya hoax, untuk menjalin kehidupan yang aman, tenteram, dan damai.

\section{Daftar Pustaka}

Ade, Verawati, and Idrus Affandi. "IMPLEMENTASI NILAI-NILAI KEARIFAN LOKAL DALAM MENGEMBANGKAN KETERAMPILAN

${ }^{31}$ Shihab, Tafsir Al-Misbah: Pesan, Kesan, Dan Keserasian Al Qur'an.

${ }^{32}$ Indonesia, Presiden Republik Indonesia, Al-Qur'an Dan Terjemah Dilengkapi Panduan Waqaf Dan Ibtida'. 
KEWARGANEGARAAN (Studi Deskriptif Analitik pada Masyarakat Talang Mamak Kec. Rakit Kulim, Kab. Indragiri Hulu Provinsi Riau).” Jurnal Pendidikan Ilmu Sosial 25, no. 1 (2016): 77.

Ahmad, Amar. "Perkembangan Teknologi Komunikasi dan Kesenjangan Informasi: Akar Informasi dan Berbagai Standarnya." Jurnal Dakwah Tabligh 13, no. 1 (2012): 137-149.

Banten, Cendekiawan Islam Jawa Barat dan Moderasi Islam di Era Disrupsi. Yogyakarta: Pustaka Senja imprint Ganding Pustaka, 2018.

Danandjaja, James. Metode Penelitian Kepustakaan. Antropologi Indonesia, 2014.

Doni, rohma Fahlepi. "Perilaku Penggunaan Smartphone pada Kalangan Remaja." Journal Speed Sentra Penelitian Engineering dan Edukasi 9, no. 2 (2017): 16-23.

Harahap, Syahrin. Islam \& Modernitas: Dari Teori Modernisasi Hingga Penegakan Kesalehan Modern. Jakarta: Penamedia Grup, 2015.

Indonesia, Departemen Agama Republik. al-Qur'an dan Terjemahnya. Surabaya: Mahkota, 1991.

Indonesia, Presiden Republik. Presiden Republik Indonesia, al-Qur'an dan Terjemah Dilengkapi Panduan Waqaf dan Ibtida'. Jakarta, 2016.

Ismail, Faisal. Islam Yang Produktif: Titik Temu Visi Keumatan dan Kebangsaan. Yogyakarta: IRCiSoD, 2017.

Karunia Assidik, Gallant. "KAJIAN IDENTIFIKASI DAN UPAYA PENANGKALAN PEMBERITAAN PALSU (HOAX) PADA PEMBELAJARAN BAHASA INDONESIA." Kemdikbud RI Badan Pengembangan dan Pembinaan Bahasa (2018).

Lipsus Internet. "Indonesia Digital 2019 : Media Sosial.” Websindo. Last modified 2019. https://websindo.com/indonesia-digital-2019-media-sosial/.

Mislikhah, St. "Kesantunan Tuturan." Ar-Raniry: International Journal of Islamic Studies 1, no. 2 (2014): 285--296.

Mohammed, Shelina J. Generation M: Young Moslem Changing The World. London: I. B. Taurs, 2016.

Mulawarman, Mulawarman, and Aldila Dyas Nurfitri. "Perilaku Pengguna Media Sosial Beserta Implikasinya Ditinjau dari Perspektif Psikologi Sosial Terapan." Buletin Psikologi 25, no. 1 (2017): 36-44.

Rasywir, Errissya, and Ayu Purwarianti. "Import Citahttp://Eksperimen Pada Sistem Klasifikasi Berita Hoax Berbahasa Indonesia Berbasis Pembelajaran Mesin.” Jurnal Cybermatika 3, no. 2 (2015): 1-8. https:/www.mendeley.com/import/.

Sartini. "Abstract: Kata Kunci:" Jurnal Filsafat 37, no. 2 (2004): 111-120. https://jurnal.ugm.ac.id/wisdom/article/view/33910/20262.

Setyabudi, M. Nur Prabowo. Pengantar Studi Etika Kontemporer. Malang: Universitas Brawijaya Press, 2017.

Tribakti: Jurnal Pemikiran Keislaman

Volume 31, Nomor 2, Juli 2020 
Setyaningsih, Rila, Abdullah Abdullah, Edy Prihantoro, and Hustinawaty Hustinawaty. "Model Penguatan Literasi Digital Melalui Pemanfaatan E-Learning." Jurnal ASPIKOM3, no. 6 (2019): 1200.

Shabuni, Muhammad Ali Ash. Shafwatut Tafasir. Juz 3. Mesir: Dar al-Shobuni, n.d.

Shihab, M. Quraish. Tafsir Al-Misbah: Pesan, Kesan, dan Keserasian al-Qur'an. Vol. 13. Jakarta: Lentera hati, 2002.

- Tafsir Al-Misbah: Pesan, Kesan, dan Keserasian al-Qur'an. Vol. 12. Jakarta: Lentera hati, 2002.

Supratman, Lucy Pujasari. "Penggunaan Media Sosial oleh Digital Native." Jurnal ILMU KOMUNIKASI 15, no. 1 (2018): 47-60.

Tsaniyah, Naimatus, and Kannisa Ayu Juliana. "LITERASI DIGITAL SEBAGAI UPAYA MENANGKAL HOAKS DI ERA DISRUPSI." Al Balagh: Jurnal Dakwah dan Komunikasi 4, no. 1 (2019): 121-140.

Walidah, Iffah Al. "Tabayyun di Era Generasi Millenial.” Jurnal Living Hadis 2, no. 2 (2018): 317.

Wan Hakimin, Fatin Nazmin Mansor \& Nik Mohd Nabil B Ibrahim ${ }^{-}$Nik Hanafi. "Kepentingan Tabayyun Dalam Mendepani Arus Globalisasi." 4th INTERNATIONAL CONFERENCE ON ISLAMIYYAT STUDIES 2018, no. September (2018): 411-421. http://conference.kuis.edu.my/irsyad/images/eproceeding/2018/1068-irsyad2018.pdf.

Yusuf, A. Muri. Penelitian Kuantitatif, Kualitatif \& Penelitian Gabungan. Jakarta: Prenada Media, 2016.

"Hati-Hati, Ini Meme 'Hoax' Atasnamakan Gus Mus." $N U$ Online. https://www.nu.or.id/post/read/75988/hati-hati-ini-meme-hoax-atasnamakangus-mus. 